Using experimental manipulation of questionnaire design and a Kenyan panel to test for the reliability of reported perceptions of climate change and adaptation

\title{
Alistair Munro
}

January 2020

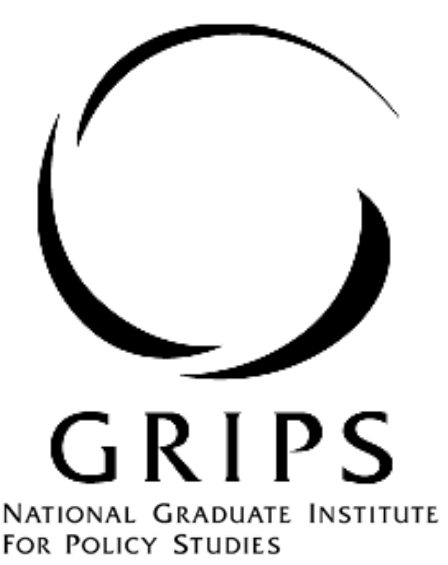

National Graduate Institute for Policy Studies

7-22-1 Roppongi, Minato-ku,

Tokyo, Japan 106-8677 


\title{
Using experimental manipulation of questionnaire design and a Kenyan panel to test for the reliability of reported perceptions of climate change and adaptation.
}

\author{
Alistair Munro* \\ National Graduate Institute for Policy Studies (GRIPS), Japan.
}

\begin{abstract}
While the use of surveys to understand perception of climate change and adaptation is common in research on agriculture, the reliability of aspects of the methodology is still largely untested. In particular there is limited evidence on (i) the degree to which measures of perception are sensitive to questionnaire design (ii) the accuracy of recall methods for climate change and (iii) the degree to which measures of adaptation based on recall from one-time surveys match the historical record. Using an established panel of farmers from across Kenya and a split sample method, I test both the sensitivity of stated perceptions of climate change to question format and the accuracy of recalled adaptations. In one treatment farmers face open-ended questions about temperature and rainfall changes while in the other treatment farmers are offered closed-end questions. Both approaches are common in the voluminous literature on climate change adaptation. Responses are highly sensitive to question format, both in the degree of perceived change and in the types of changes. Stated adaptations are not so sensitive to question format, but still diverge. Stated adaptations do not correspond well to the historical record of farming practices over the 15 years of the panel. Overall, the evidence suggests that researchers and policy-makers should be highly cautious in their use of subjective perceptions of climate change and the use of adaptation measures based on recall data.
\end{abstract}

Keywords: climate change adaptation, framing effects, recall bias, Kenya

*Thanks are due to Yoko Kijima, Tomoya Matsumoto, Chikako Yamauchi and the REPEAT survey team led by Bbosa Davis for data collection and assistance on task design. Thu Trang Vu provided capable research assistance. I gratefully acknowledge the useful feedback from EAERE conference attendees and funding from the National Graduate Institute for Policy Studies for piloting work and from JSPS Kakenhi Grant Number 25101002 for the main field work.

*Corresponding author. National Graduate Institute for Policy Studies (GRIPS), Roppongi 7-22-1, Minato-ku, Tokyo, Japan, 106-8677. Email: alistair-munro 'at' grips.ac.jp

January 15,2020 


\section{Introduction.}

Studies on climate-change adaptation in many developing countries have relied to a large extent on surveys of self-reported perception of change and adaptations, IPCC (2014). Despite the widespread use of the method, a number of important questions about its reliability remain unanswered. A particular issue with surveys of perception in general is the degree to which responses are guided by the question format (Schwarz (1999), Schuman and Presser (1996)). An instrument that asks close-ended questions about, for example, recent experience of drought or higher temperatures may obtain very different results from an open-ended format in which subjects are simply asked if they have perceived any changes in rainfall, for example, and invited to provide details if any change has been noticed. The reliability of other aspects of climate change data from surveys is also unclear. For example, farmers may also suffer from various forms of recall bias when asked to state adaptations that they have made, (Beegle et al. (2012)) especially when they are asked to think about changes over long periods of time for which accurate paper or digital records are not available. In a one shot or cross sectional study, recall bias or inaccuracy may be hard to check (Assaad et al. (2018)). Moreover, recall bias and question format effects may interact, if for example the saliency of particular adaptations are also affected by the open-ended or closed methods used to obtain perceptions of climate change. This may be particularly acute when memories are fuzzy and small changes in wording bring to mind quite different pictures of the past (Kahneman (2003)). In addition to such psychological effects, some surveys may be structured in such a way that farmers who do not report climate change may then not face questions about adaptation. To the extent that measured perceptions of climate change are influenced by the questionnaire design this may lead to further sources of bias.

In this research I use a split sample method coupled with a long-running panel survey of Kenyan farmers to examine the reliability of farmer's recall and to check for framing effects in survey design. For the latter, half the subjects receive one format for the climate change perception survey while half the subjects receive a different format. Both formats are widely used. I also compare the perceived change in climate to satellite records. With regards to adaptation, I compare what the farmers say that they have changed, to the evidence of change obtained by comparing contemporaneous reports of farming practices over different waves of the survey. In this way I make four main contributions: first, I examine experimentally the sensitivity of climate change reports to question format; second I show the degree to which stated adaptations may be linked to survey design; third I test the degree to which recall of adaptations matches the historical record and finally I contribute to the literature on the relationship between subjective perceptions of climate change and more objective measures provided by satellite data (Hansen et al. (2012)). The general and robust result is that the level and type of perceived climate change is very sensitive to the form of the survey; second, neither approach is particularly accurate when the farmers' reports of climate change are compared to the satellite record. 
Third, recalled adaptation is sensitive to question format even controlling for reported changes in climate. Fourth, recalled adaptations of farming practices are only weakly related to the changes calculated on the basis of contemporaneous reports of practices. In short therefore, none of the aspects of the standard survey appear to be reliable. Of course, the sample is limited to one country, but the methods used to obtain the data and the sort of subjects who provide the answers are quite typical. Taken altogether, the results therefore cast doubt on one routinely used method of measuring climate change perception and adaptation.

\section{Background.}

IPCC (2014) summarizes much of the available evidence that indicates climate change is likely to affect negatively agricultural production in sub-Saharan Africa. According to a number of different models of climate, at the end of the century median temperature increase of between 3C and 4C in Africa is predicted, which is approximately 1.5 times the global change. This is expected to result in a significant loss of yield for key staples, such as maize, sorghum, millet, groundnut, and cassava, of between 8-22 percent by 2050 under a business as usual scenario.

Much of the data that feeds into IPCC (2014) is based on surveys in which agricultural households are asked about perception of climate change and then about their adaptations. A well-known and pioneering example is Maddison (2007) which reports on a multiple country study. This report is notable for its attention to the issue of the reliability of such methods and is replete with caveats, yet despite its extensive notes of caution, many researchers have used broadly similar methods to explore how rural communities adapt to changes in precipitation and temperature. Typically, the studies ask farmers first about perceptions of climate change and then ask them to explain what adaptations they have made so far.

There are different ways that perceptions are elicited, but in one commonly employed method, the questions used are open ended. Subjects are simply asked about whether they have noticed any long term changes in temperature and precipitation patterns. It is up to the farmer to respond how they see fit. After the responses have been recorded, a protocol is used to convert the answers into standardized measures of perceived change. For example 'hotter' would lead to 'temperature rise' being coded 1, whereas if the respondent had not mentioned temperature or had said temperatures had fallen then this item would be coded zero. In a second approach (e.g. Habtemariam et al. (2016)), subjects are faced with specific questions. With the first approach there is a danger that the subjects will simply forget to mention something important, or will give a limited response in order to hurry up the interview ((Geer, 1991)). With the second method, there is a concern that farmers will anchor their responses on the questions or engage in yeah saying or some other form of enumerator or questionnaire-affected bias ((Krosnick, 
1999)). In both cases, there is also a possibility that the subjects' responses will be subject to recall bias (Assaad et al. (2018)).

The number of studies that use this basic method is large and covers many countries across the industrialised and developing world. Table 1 is a non-systematic summary of some of the papers that use this basic methodology, designed to show the variety of countries where the method has been applied and the fact that its use is current and not confined to historical studies. A number of these papers are cited in IPCC (2014). One major source of data for example is the CEEPA project Waha et al. (2016) that involved 9,500 households across 11 countries (Burkina Faso, Cameroon, Ghana, Niger and Senegal, Egypt, Ethiopia, Kenya, South Africa, Zambia and Zimbabwe) in subSaharan Africa, with a summary of the main findings in Maddison (2007). That study used open ended questions for both perception of climate change and adaption. ${ }^{1}$ Openended questions are most commonly used, but as Table 1 shows close-ended versions are also employed.

When farmers are asked about their adaptations there is also a possibility of recall bias or yeah saying (Choi and Pak (2005)). There is also a concern that the answers to the first part of the questionnaire may influence how farmers answer the second section by affecting the saliency of some historical events (Weber (2010)). Furthermore, with a typical, one shot survey it is not possible to check whether these adaptations have actually occurred or whether their extent is being over or understated. In some cases, actual weather data may be available in which case at least, the accuracy of farmer perceptions of climate change can be investigated. ${ }^{2}$

These concerns about the reliability of the methods used to measure perception and adaptation are summarised in the key null hypotheses of this paper.

1. The format of the perceptions questions of the questionnaire does not affect the recorded perceptions.

2. The stated perceptions of climate change match the available data on climate

\footnotetext{
${ }^{1}$ Marlon et al. (2018) is an example of a study of risk perceptions across the wider community and contains a useful summary on the strength of the relationship between perception and reality of climate change.

${ }^{2} \mathrm{~A}$ third issue, one that is tangential to the main point of this paper is whether perception is a necessary condition for adaptation. In many papers cited, only farmers who indicate some form of climate change are asked about adaptation. This creates a potential problem of selection bias when the relationship between climate change and adaptation is to be estimated. At a deeper level, it is not clear that perception is necessary for adaptation. Farmer A, for example, may perceive change while B does not. Farmer A adapts and B notices that farmer A is producing higher yields or earning a higher income and then copies farmer A. Such transmission of technical knowledge through social networks is typical. I would argue that B also adapts to climate change, but in many surveys this adaptation would not be recorded.

${ }^{3}$ For example "The average temperature in recent years is higher than that in 10 years ago" (strongly disagree to strongly agree, 7 point scale)
} 
Table 1: Perception and Adaptation: Some Examples of Research.

\begin{tabular}{|c|c|c|c|c|c|}
\hline Source & Countries & $\begin{array}{c}\text { Perception } \\
\text { Question } \\
\text { Type }\end{array}$ & $\begin{array}{c}\text { Adaptation } \\
\text { Question } \\
\text { Type }\end{array}$ & $\begin{array}{c}\mathrm{CC} \\
\text { Verified }\end{array}$ & $\begin{array}{l}\text { Adaptation } \\
\text { Verified }\end{array}$ \\
\hline $\begin{array}{c}\text { Maddison (2007) (CEEPA } \\
\text { survey) }\end{array}$ & $\begin{array}{c}\text { Africa } \\
\text { sub-Sahara }\end{array}$ & $\mathrm{O}$ & $\mathrm{O}$ & No & No \\
\hline $\begin{array}{c}\text { Kurukulasuriya et al. (2006) } \\
\text { (CEEPA) }\end{array}$ & $\begin{array}{c}\text { Africa } \\
\text { sub-Sahara }\end{array}$ & $\mathrm{O}$ & $\mathrm{O}$ & No & No \\
\hline Deressa et al. (2009)(CEEPA) & Ethiopia & $\mathrm{O}$ & $\mathrm{O}$ & No & No \\
\hline Silvestri et al. (2012) & Kenya & $\mathrm{O}$ & $\mathrm{O}$ & No & No \\
\hline Habiba et al. (2012) & Bangladesh & NA & $\mathrm{NA}$ & No & No \\
\hline De Jalón et al. (2015) & Kenya & C- Likert & NA & No & No \\
\hline Fosu-Mensah et al. (2012) & Ghana & $\mathrm{C}$ & $\mathrm{O}$ & No & No \\
\hline Gbetibouo (2009) (CEEPA) & South Africa & $\begin{array}{l}\text { O with } \\
\text { prompt }\end{array}$ & $\mathrm{O}$ & No & No \\
\hline Le Dang et al. (2014) & Vietnam & C - Likert ${ }^{3}$ & $\mathrm{C}$ & No & No \\
\hline Roco et al. (2015) & Chile & $\mathrm{O}$ & NA & Yes & NA \\
\hline Habtemariam et al. (2016) & Ethiopia & $\mathrm{C}$ & NA & Yes & $\mathrm{NA}$ \\
\hline Battaglini et al. (2009) & $\begin{array}{c}\text { France, } \\
\text { Germany, } \\
\text { Italy }\end{array}$ & $\mathrm{O}$ & $\mathrm{O}$ & NA & NA \\
\hline Singh et al. (2018) & India & $\mathrm{O}$ & $\mathrm{O}$ & No & No \\
\hline Bryan et al. (2013) & Kenya & $\mathrm{O}$ & $\mathrm{C}$ & Yes & No \\
\hline
\end{tabular}


change.

3. The pattern of stated adjustments to climate change is not affected by the format of the perceptions section.

4. The pattern of stated adjustments matches historical records of adjustments undertaken by farmers.

While speculation about each of these claims is common, it is the second hypothesis that has received most attention in prior work (e.g. Simelton et al. (2013) ). The evidence seems to be that within relatively shorter time periods, the match between perception and meteorological data is poor, but that is slightly better over longer periods (Fosu-Mensah et al. (2012), Li et al. (2014), Budhathoki and Zander (2019)).

If all the hypotheses hold true, then confidence in accuracy and robustness of the existing perceptions and adaptations literature is enhanced: farmers are making reliable inferences about climate changes; their reporting of these changes is not sensitive to questionnaire design; their reporting of climate change adaptations is also not sensitive to questionnaire design and it is accurate. However, to the extent that any of the hypotheses are rejected, the current methodology may have to be revised.

\section{Method.}

To test the hypotheses, I use the RePEAT survey, a long-running panel study that investigates farming communities in Ethiopia, Uganda and Kenya (Yamano et al., 2004; Tanaka and Munro, 2014). In fact, this study only concerns Kenya where the survey has been conducted four times since 2003/04, with the most recent survey done in 2018. Farmers face a detailed set of questions about crop choice, farming practices, conservation methods and so on, as well socio-demographic questions about their families and, in certain years, special modules that focus on particular issues such as mobile banking or family planning. In Kenya, villages from 14 counties are included, mostly from the less arid regions and more heavily populated areas in the west and south-west of the country. Several have been exposed to droughts over the period covered by the panel. The repetition of key questions about farming practices across waves gives us an opportunity to test a number of hypothesis about how the questionnaire affects responses and whether the farmers are subject to a significant degree of recall bias. Meanwhile the introduction of a module on perceptions of climate change for Kenya in 2018, enables us to test hypotheses about the impact of question framing.

A survey of this kind may have its own biases. For example, some recent research (e.g. Desiere and Jolliffe (2018)) has questioned the reliability of farmer-provided yield data. I do not use yield data here, but note that the RePEAT panel shows a high level of internal consistency over the years and has been successfully and reliably used many times to examine the evolution of farming practices and technology use (e.g. Muto and Yamano (2009); Mwesigye and Matsumoto (2016)) as well as other social issues (e.g. Gray (2011); Yamauchi and Manang (2019)) in East Africa. 
Table 2: Question Variants for Temperature

\begin{tabular}{c|c}
\hline Version 1 & Version 2 \\
\hline $\begin{array}{c}\text { Thinking back to 2003 (when the first } \\
\text { Repeat survey was done) have you } \\
\text { noticed any long term changes in the } \\
\text { average temperature on your farm? } \\
\text { (please explain) }\end{array}$ & $\begin{array}{c}\text { Thinking back to 2003 (when the first } \\
\text { any of the following long term changes in } \\
\text { the average temperature on your farm? }\end{array}$ \\
& $\begin{array}{l}\text { 1. Increased average temperatures } \\
\text { 2. Decreased average temperatures } \\
\text { 3. Altered Temperature range (the gap } \\
\text { between lowest and highest tempera- } \\
\text { tures has got bigger/smaller) }\end{array}$ \\
\hline
\end{tabular}

In the climate change module of the 2018 survey for Kenya, subjects are randomly assigned one of two variants (see Table 2 for the temperature questions). In variant 1 , the questions are open-ended. Following the pattern of the literature, I then use regular expressions to search for clear indications of meaning in the responses. In the open-ended version there is one question about average rainfall. In the close-ended version there are six questions in total, two each about the amount of rainfall, the timing of rainfall and the number of droughts. The first pair of these questions corresponds most closely to the open ended question, so in coding I initially ignore phrases such as drought when coding for changes in total rainfall. Nevertheless it seems reasonable that some people when asked, for example, about 'long term changes in the average rainfall on your farm' might mention increased or decreased drought to mean decreased or increased rainfall. So I have an alternative coding for changes in rainfall that includes words for drought. As this makes only small changes to the results reported below, I largely set this issue aside.

In both versions of the questionnaire, subjects are asked follow up questions about specific adaptations. The wording is 'what adjustments in your farming have you made to these long term shifts?', but to be clear, the question is asked whether or not the farmers have identified particular climactic shifts. After the question is asked, the subjects are presented with a list of 24 possible shifts and invited to pick any or all that apply to them. The list is a standard one taken from Maddison (2007) (see Appendix for a complete list). The RePEAT panel has its own established methods, which means that not all the questions about farming practice map easily to the 24 possible shifts. For example there are no questions about prayer in the RePEAT questionnaire. Perhaps more importantly the survey instrument contains no items on planting dates, one variable that might be quite sensitive to changes in climate. The table below shows the correspondence between the itemized adaptations and some questions in the core of the RePEAT questionnaire. 
Table 3: Mapping Reported Adaptations to the RePeat data

\begin{tabular}{|c|c|}
\hline Adaptation & RePEAT data used \\
\hline Planted different varieties & $\begin{array}{l}\Delta \text { number varieties; } \Delta \text { number varieties (weighted by } \\
\text { area) }\end{array}$ \\
\hline Planted different crops & $\begin{array}{l}\text { number of new crops; } \Delta \text { number crops; } \Delta \text { number crops } \\
\text { (weighted) }\end{array}$ \\
\hline Crop diversification & $\Delta$ number crops; $\Delta$ number crops (weighted); \\
\hline Intercropping & $\begin{array}{l}\Delta \text { fraction plots intercropped; } \Delta \text { fraction plots inter- } \\
\text { cropped (weighted) }\end{array}$ \\
\hline Changed use of chemicals and fertilisers & $\begin{array}{l}\Delta \text { fraction plots with fertilizer; } \Delta \text { fraction plots with fer- } \\
\text { tilizer (weighted) }\end{array}$ \\
\hline Change from farming to non-farming activity & $\Delta$ number business activities \\
\hline Changing quantity of land under cultivation & $\Delta$ cultivated area \\
\hline Changing livestock versus crops & $\Delta$ fraction area used for pasture and fodder \\
\hline Made adjustments to livestock management & $\Delta$ fraction livestock outside reared \\
\hline Shading and sheltering / tree planting & $\begin{array}{l}\Delta \text { trees; } \Delta \text { trees for conservation; } \Delta \text { fraction plots with } \\
\text { trees for conservation; }\end{array}$ \\
\hline $\begin{array}{l}\text { Change in water conservation; Used soil conser- } \\
\text { vation techniques }\end{array}$ & $\begin{array}{l}\Delta \text { plots with water/soil conservation; } \Delta \text { plots with wa- } \\
\text { ter/soil conservation (weighted) }\end{array}$ \\
\hline $\begin{array}{l}\text { Changed use of irrigation /groundwater / wa- } \\
\text { tering }\end{array}$ & $\begin{array}{l}\Delta \text { plots not using rainwater; } \Delta \text { plots not using rainwater } \\
\text { (weighted) }\end{array}$ \\
\hline
\end{tabular}

For some adaptations - e.g inter-cropping or crop diversification or changes in fertilizer use - the match to the pre-existing RePEAT question is very close. On the other hand, there are some adaptations, such as prayer where we have no data or questions such as insurance where the question is only asked in one wave of the panel. For some other questions, the match between suggested adaptation and the RePEAT questionnaire is not so close or the adaptation is very general, meaning there are many possible changes that might fit into the category. These adaptations include 'made adjustments to livestock management' and 'used soil conservation techniques'. In the results section, I consider a number of the more obvious possible variables from the RePEAT data, but it is conceivable that some instances of adaptation may not be picked up in the panel.

For the historical data on climate I use the MERRA-2 dataset ${ }^{4}$ which provides daily data at a resolution of 0.5 degrees. Data from 2003 to 2017 are used. Given the location of the villages in the RePEAT survey, this yields eight distinct cells each of which is approximately $55 \times 55 \mathrm{~km}$. For comparing perceptions of temperature and rainfall change

\footnotetext{
${ }^{4}$ These data were obtained from the NASA Langley Research Center (LaRC) POWER Project funded through the NASA Earth Science/Applied Science Program.
} 
to the historical data I use two year means from the beginning and end of the survey period (2003-2004 and 2016-2017).

\section{Results.}

Altogether there are 1195 observations for the climate change perception question. Some 590 subjects face version 1 while 608 see version 2. Balance tests show no significant differences between the two sub-samples for age groups, gender, household size, farm area and education.

\subsection{Perceptions of Climate and Questionnaire Format.}

I set out the perception of climate results, for versions 1 and 2 of the survey. First, temperature change which is shown in Figure 1a. Generally participants perceive that temperature is increasing, but the reported perception is much stronger in the closed-end version by 24 percentage points and the difference is statistically significant $(\mathrm{p}<0.01$, binomial test on proportion reporting hotter).

Next I look at rainfall, Figure 1b. Asked about changes in rainfall, $44.9 \%$ of respondents in version 1 do not mention any noticed change. A few people (10.8\%) say it is wetter and $44.8 \%$ say it has become drier. In contrast, few $(26 \%)$ respondents say that there is no change in version 2. Most (59.1\%) declare that it has become drier while a smaller proportion argue that it is wetter. The distribution of Versions 1 and 2 results are therefore very different $(\mathrm{p}<0.001$, chi-squared test).

For droughts, the differences between the two versions is stark (see Figure 1c). This is because few people mention droughts in the open-ended questions, perhaps because of the way the question was worded. Again, therefore, the distribution of answers is significantly different between the two versions ( $p<0.001$, chi-squared test).

Is the rainfall result sensitive to the definition of rainfall changes used in the regular expressions? Specifically, does coding 'increased drought' as 'decreased rainfall' etc. change the results? As can be seen from Figure 1dThe answer is 'slightly' in that the percentage declaring no-change is lower when the drought answers are coded for rainfall changes, and the ratio of drier to no change is now greater than 1 in both versions of the questionnaire. However, the distribution of the answers is still highly statistically significant $(p<0.001$, chi-squared test).

\subsection{Stated adaptations and questionnaire format.}

I test whether the version affects the likelihood of reporting a particular adaptation. To do this, using a fixed effects logit model, I regress whether the respondent states they have adopted a particular adaptation on a dummy for the questionnaire version and the results of the questions on changes in rain and temperature. For temperature, rain and droughts we have dummmies for no change reported and rises. The omitted category is therefore 'fall'. The fixed effects in the model are at the sub-county level, meaning that 


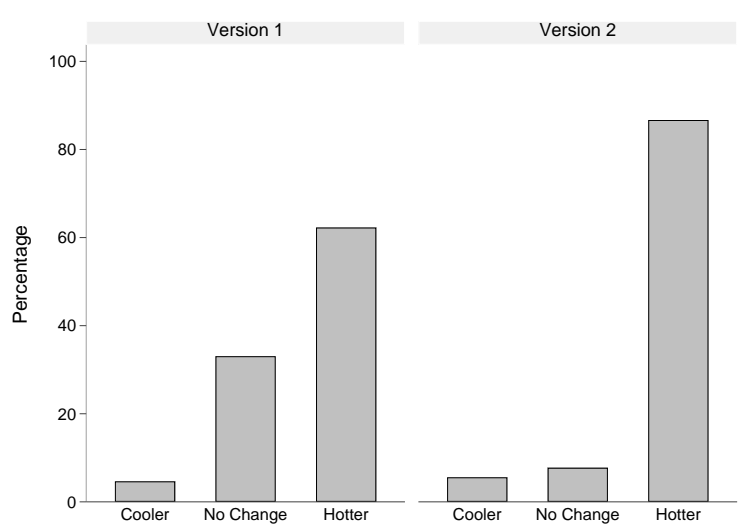

(a) Temperature

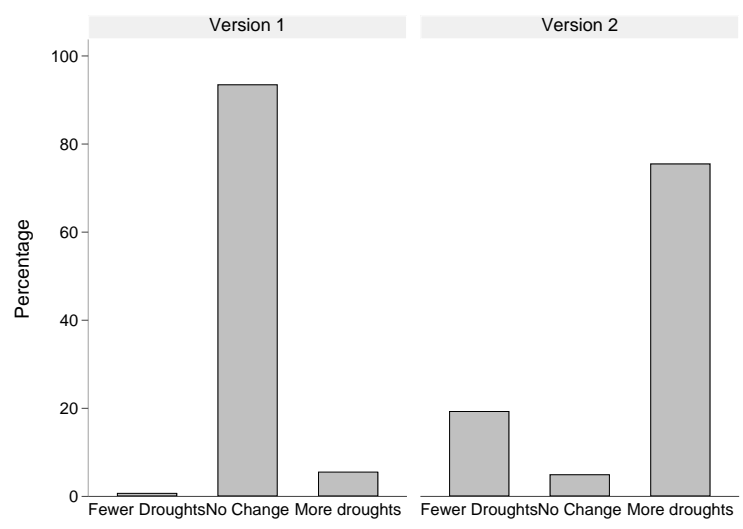

(c) Drought

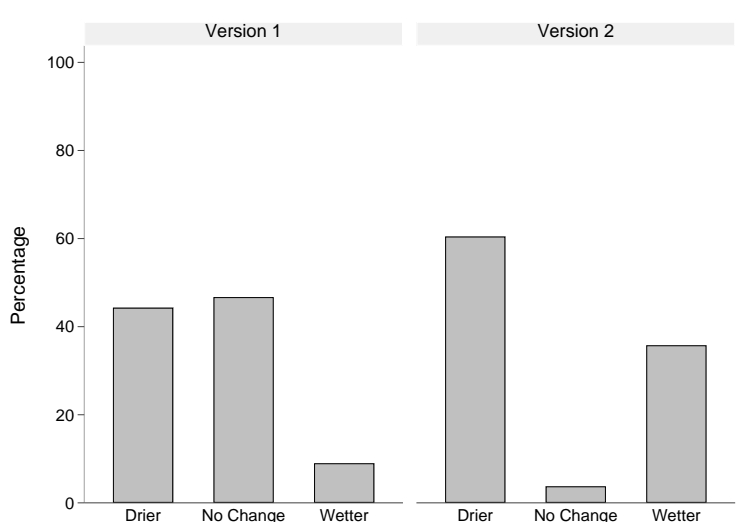

(b) Rain 1

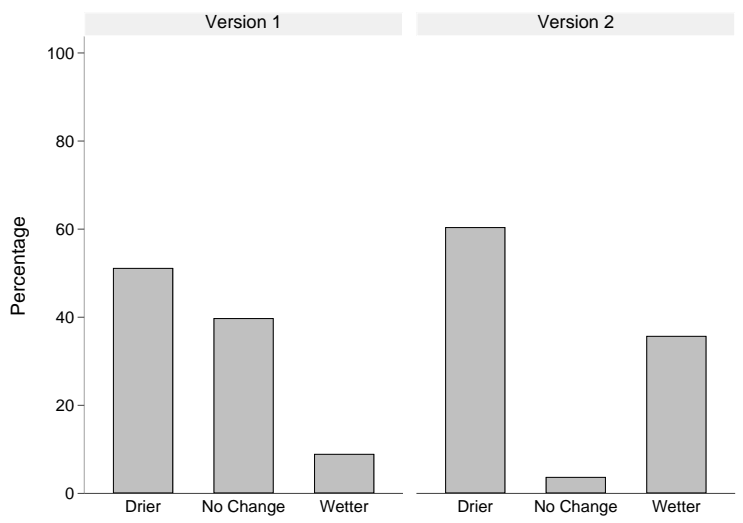

(d) Rain 2

Figure 1: Effect of Version on Reported Climate Change

the variations in climate and its change (rather than the perception of change) will be picked up by the fixed effects. ${ }^{5}$ The results are reported in Tables 4-6 for 21 adaptations in the order that they are listed in the Appendix. ${ }^{6}$

\footnotetext{
${ }^{5}$ Kenya has 47 counties. The number of sub-counties per county varies, but is typically $10-15$ so that the within-sub-county climate variation is small. I use fixed effects to absorb the myriad of influences on adaptation that are common to a locality. I do not use fixed effects at the village level since for about half the sample there is only one household per village. For many other villages there are only two or three households in the sample. Overall I have 43 sub-counties in the sample.

${ }^{6}$ The omitted adaptations are 'To non-farming' 'Other' and 'No adaptation'. The first of these is omitted because only a few participants respond that they have switched away from farming and this produces a lack of variation within sub-counties that produces a non-convergent model. There is no
} 
Table 4: Perception, Version and Adaptation I

\begin{tabular}{lccccccc}
\hline VARIABLES & Varieties & Crops & Diversify & Intercrop & Dates & Earlier & Later \\
\hline \multirow{2}{*}{ Closed version } & & & & & & & \\
& $0.086^{* *}$ & 0.099 & $0.115^{* * *}$ & $0.103^{* * *}$ & 0.055 & 0.003 & 0.003 \\
Temperature, No Change & $(1.99)$ & $(1.62)$ & $(3.60)$ & $(3.53)$ & $(0.89)$ & $(0.04)$ & $(0.04)$ \\
& 0.090 & -0.029 & 0.044 & 0.088 & 0.029 & $0.223^{* *}$ & 0.060 \\
Temperature, Hotter & $(1.12)$ & $(-0.31)$ & $(0.68)$ & $(1.29)$ & $(0.27)$ & $(2.39)$ & $(0.69)$ \\
& 0.065 & -0.026 & 0.007 & 0.087 & 0.075 & 0.075 & $0.151^{*}$ \\
Rain, No Change & $(0.84)$ & $(-0.30)$ & $(0.10)$ & $(1.33)$ & $(0.79)$ & $(0.83)$ & $(1.92)$ \\
& -0.052 & $-0.095^{*}$ & -0.039 & -0.081 & 0.002 & -0.083 & 0.000 \\
Rain, Wetter & $(-1.09)$ & $(-1.69)$ & $(-0.94)$ & $(-1.53)$ & $(0.05)$ & $(-1.56)$ & $(0.01)$ \\
& -0.071 & $-0.162^{* * *}$ & $-0.129^{*}$ & -0.039 & -0.016 & $-0.225^{* * *}$ & $0.074^{*}$ \\
Drought, No Change & $(-1.44)$ & $(-2.79)$ & $(-1.94)$ & $(-0.98)$ & $(-0.32)$ & $(-4.58)$ & $(1.66)$ \\
\multirow{2}{*}{ Drought, More droughts } & 0.085 & 0.096 & $0.133^{* *}$ & 0.075 & 0.086 & -0.076 & -0.013 \\
& $(1.38)$ & $(1.13)$ & $(2.31)$ & $(1.64)$ & $(0.98)$ & $(-0.70)$ & $(-0.14)$ \\
& -0.034 & 0.028 & 0.012 & -0.058 & -0.041 & -0.029 & $-0.156^{* *}$ \\
Observations & $(-0.52)$ & $(0.38)$ & $(0.18)$ & $(-0.99)$ & $(-0.45)$ & $(-0.34)$ & $(-2.19)$ \\
& & & & & & & \\
& 1,070 & 1,050 & 1,058 & 1,008 & 987 & 1,009 & 1,099 \\
\hline
\end{tabular}

Notes. $^{* * *},{ }^{* *},{ }^{*}$ indicate two-sided significance levels at 1,5 , and $10 \%$, respectively; standard errors (in parentheses) clustered the sub-country level. Marginal effects, evaluated for the highest outcome at means of the right-hand side variables.

Table 5: Perception, Version and Adaptation II

\begin{tabular}{|c|c|c|c|c|c|c|c|}
\hline VARIABLES & Land & From crops & To crops & Livestock & Farm up & Water up & Water down \\
\hline Closed version & $\begin{array}{l}0.051 \\
(0.61)\end{array}$ & $\begin{array}{l}0.045 \\
(0.88)\end{array}$ & $\begin{array}{c}-0.185^{* * *} \\
(-3.32)\end{array}$ & $\begin{array}{l}0.010 \\
(0.13)\end{array}$ & $\begin{array}{l}0.059 \\
(0.64)\end{array}$ & $\begin{array}{l}0.058 \\
(1.09)\end{array}$ & $\begin{array}{c}-0.132^{* *} \\
(-2.56)\end{array}$ \\
\hline Temperature, No Change & $\begin{array}{c}-0.181^{*} \\
(-1.85)\end{array}$ & $\begin{array}{l}0.002 \\
(0.02)\end{array}$ & $\begin{array}{l}0.190 \\
(1.48)\end{array}$ & $\begin{array}{l}-0.034 \\
(-0.35)\end{array}$ & $\begin{array}{l}0.078 \\
(0.75)\end{array}$ & $\begin{array}{l}0.010 \\
(0.09)\end{array}$ & $\begin{array}{l}0.285 \\
(1.18)\end{array}$ \\
\hline Temperature, Hotter & $\begin{array}{l}-0.152 \\
(-1.57)\end{array}$ & $\begin{array}{l}0.057 \\
(0.61)\end{array}$ & $\begin{array}{l}0.142 \\
(1.34)\end{array}$ & $\begin{array}{l}-0.053 \\
(-0.57)\end{array}$ & $\begin{array}{l}0.077 \\
(0.82)\end{array}$ & $\begin{array}{l}0.064 \\
(0.66)\end{array}$ & $\begin{array}{l}0.068 \\
(0.76)\end{array}$ \\
\hline Rain, No Change & $\begin{array}{l}0.000 \\
(0.01)\end{array}$ & $\begin{array}{l}0.071 \\
(1.09)\end{array}$ & $\begin{array}{l}0.066 \\
(0.82)\end{array}$ & $\begin{array}{l}0.010 \\
(0.19)\end{array}$ & $\begin{array}{l}0.021 \\
(0.27)\end{array}$ & $\begin{array}{l}0.055 \\
(0.90)\end{array}$ & $\begin{array}{l}0.013 \\
(0.21)\end{array}$ \\
\hline Rain, Wetter & $\begin{array}{l}-0.029 \\
(-0.57)\end{array}$ & $\begin{array}{l}0.077 \\
(1.19)\end{array}$ & $\begin{array}{l}0.107 \\
(1.37)\end{array}$ & $\begin{array}{l}-0.025 \\
(-0.52)\end{array}$ & $\begin{array}{l}0.093 \\
(1.21)\end{array}$ & $\begin{array}{l}0.008 \\
(0.12)\end{array}$ & $\begin{array}{l}-0.055 \\
(-0.94)\end{array}$ \\
\hline Drought, No Change & $\begin{array}{l}-0.053 \\
(-0.53)\end{array}$ & $\begin{array}{l}0.107 \\
(1.21)\end{array}$ & $\begin{array}{c}-0.155^{*} \\
(-1.67)\end{array}$ & $\begin{array}{l}-0.150 \\
(-1.40)\end{array}$ & $\begin{array}{l}0.038 \\
(0.34)\end{array}$ & $\begin{array}{l}0.107 \\
(1.22)\end{array}$ & $\begin{array}{c}-0.294 * * * \\
(-2.73)\end{array}$ \\
\hline Drought, More droughts & $\begin{array}{l}-0.091 \\
(-1.10)\end{array}$ & $\begin{array}{l}0.097 \\
(0.95)\end{array}$ & $\begin{array}{l}-0.053 \\
(-0.52)\end{array}$ & $\begin{array}{c}-0.192^{* *} \\
(-2.01)\end{array}$ & $\begin{array}{l}-0.028 \\
(-0.28)\end{array}$ & $\begin{array}{l}0.074 \\
(0.80)\end{array}$ & $\begin{array}{l}-0.094 \\
(-1.05)\end{array}$ \\
\hline Observations & 1,032 & 775 & 929 & 982 & 563 & 770 & 452 \\
\hline
\end{tabular}

clustered the sub-county level. Marginal effects, evaluated for the highest outcome at means of the right-hand side variables.

evidence from the mean responses that this variable is sensitive to the version of the questionnaire. 
Table 6: Perception, Version and Adaptation III

\begin{tabular}{lccccccc}
\hline VARIABLES & Fertiliser & Con. up & Con. down & Soil & Shading & Insurance & Prayer \\
\hline \multirow{2}{*}{ Closed version } & 0.097 & $0.195^{* * *}$ & -0.043 & 0.040 & $0.089^{* * *}$ & 0.001 & $-0.115^{* *}$ \\
& $(1.21)$ & $(3.95)$ & $(-0.28)$ & $(0.43)$ & $(3.02)$ & $(0.14)$ & $(-2.30)$ \\
Temperature, No Change & -0.042 & -0.026 & $0.502^{* * *}$ & -0.118 & 0.032 & -0.699 & 0.183 \\
& $(-0.39)$ & $(-0.25)$ & $(3.09)$ & $(-1.05)$ & $(0.46)$ & $(-1.48)$ & $(0.96)$ \\
Temperature, Hotter & -0.008 & -0.010 & $0.268^{*}$ & -0.058 & 0.061 & -0.699 & -0.031 \\
& $(-0.08)$ & $(-0.10)$ & $(1.95)$ & $(-0.54)$ & $(0.94)$ & $(-1.48)$ & $(-0.30)$ \\
Rain, No Change & 0.009 & -0.053 & 0.043 & -0.012 & -0.031 & 0.001 & -0.019 \\
\multirow{2}{*}{ Rain, Wetter } & $(0.14)$ & $(-0.96)$ & $(0.50)$ & $(-0.21)$ & $(-0.74)$ & $(0.15)$ & $(-0.43)$ \\
Drought, No Change & -0.027 & -0.050 & 0.073 & 0.022 & -0.028 & 0.001 & -0.045 \\
\multirow{2}{*}{ Drought, More droughts } & $(-0.44)$ & $(-0.90)$ & $(0.93)$ & $(0.41)$ & $(-0.72)$ & $(0.15)$ & $(-0.99)$ \\
& 0.029 & 0.002 & -0.154 & 0.015 & $0.121^{* * *}$ & 0.001 & -0.089 \\
Observations & $-0.28)$ & $(0.03)$ & $(-0.80)$ & $(0.13)$ & $(2.59)$ & $(0.15)$ & $(-1.24)$ \\
& $(-1.38)$ & $-0.222^{* *}$ & -0.037 & -0.063 & -0.004 & -0.000 & 0.007 \\
& & $(-2.09)$ & $(-0.40)$ & $(-0.77)$ & $(-0.07)$ & $(-0.03)$ & $(0.10)$ \\
\hline
\end{tabular}

Notes. $^{* *},{ }^{* *},{ }^{*}$ indicate two-sided significance levels at 1,5 , and $10 \%$, respectively; standard errors (in parentheses) clustered the sub-county level. Marginal effects, evaluated for the highest outcome at means of the right-hand side variables.

There are two notable features of the results in Tables 4-6. First, the version often has a significant and large direct impact on the probability of reporting an adaptation. ${ }^{7}$ The figures in the tables are marginal effects, so it worth pointing out that the impact of the version is typically as large as the impact of perceptions of change. Out of twentyone cases there are eight where the impact is statistically significant at the 5 per cent level. There is not an obvious pattern to the sign of the effects. Subjects who faced the closed version of the questionnaire were more likely to report that they had changed varieties, diversified their crops, intercropped, raised soil conservation and raised tree planting for shade. In contrast, they were less likely to report a switch towards crop use of land, lowering use of irrigation water and prayer. It is not clear what inference can be made from this pattern, but it is possible that the strong version effects for the initial adaptations represent order effects. While there are often significant links between version and reported adaptation, there are few strong relationships between the adaptation variable and the other right-hand side variables. For example, there are no significant relationships between any of the climate variables and the planting of more varieties or the use of shading. Looking at the climate variables, there is no single

\footnotetext{
${ }^{7}$ The impact of the questionnaire format may also affect the probability indirectly through its influence on the reporting of particular climate changes. Thus the coefficient on the version dummy may underor overestimate the overall influence of the survey format on measures of adaptation. Leaving out the subjective reports of climate change, however, does not change the basic pattern of results reported in this section.
} 
perceived change that impacts across a large number of adaptations. ${ }^{8}$

\subsection{Climate change perception,}

To test whether the subjective reports of climate change accord with the satellite record, I compare the reports of change to satellite evidence. Since the outcome variable is naturally ordered, it might seem most appropriate to use an ordered logit model, but as Figure 1 suggests, the effect of the questionnaire version does not appear to be monotonic - rather the closed version tends to yield fewer 'no change' answers. I therefore use a multinomial logit model. In Table 7 the dependent variable is change in temperature as perceived by respondents in the survey. This takes on the value 0 , if subjects state that temperature has dropped, 2 if they state temperature has risen and 1 if they do not claim that temperature has risen or fallen. The dependent variable is the same in the second equation, while in the third equation the dependent variable is perceived change in annual precipitation, measured in the same way. The right hand side variables include version as well as the change in each variable as measured by satellite. To measure change I take the difference between the mean figure for the last two years leading up to the survey (2016-2017) and the two years (2003-2004) when the first wave of RePeat was conducted. For the mean temperature and precipitation changes I just use daily figures and take the mean; for the max. temperature variable I take the maximum value over each two year window.

The basic lesson of Table 7 is that stated or perceived climate change is positively related to measured changes in mean temperature and rainfall. These relationships are robust to changes in the periods we use to estimate the changes. They remain if, for example, we raise the period over which mean is calculated to three years or four years. Another feature of these results is that in all the equations the version variables are statistically significant for the rise outcome. Using the close-ended version is associated with an increased probability that an increase in temperature or rainfall is reported. Perhaps more interesting is the fact that the size of the effect of the version indicator is similar to the size of the effect of changes in actual rainfall or temperature. All the coefficients are positive for the Version variable, meaning that, as suggested by the figures, the use of the closed ended questionnaire tends to lower the proportion of individuals reporting 'no change' and increases those reporting drops or rises. For temperature, however, the marginal effects are not significant for the drop in temperature outcome. For rainfall both drop and rise coefficients are highly significant. Although the variables in the model that are based on satellite data are statistically significant, this should not be taken to mean that there is a very strong relationship between the satellite data and the perceived changes. In fact the raw correlation between perception and satellite

\footnotetext{
${ }^{8}$ This absence may be due to the use of the fixed effects model, which means that the climate change variables only pick-up the the impact of differences between perceptions and the satellite data. ${ }^{9}$
} 
Table 7: Perceived Climate Change and Satellite Measurements.

\begin{tabular}{lccc}
\hline \hline & Mean temp & Max temp & Rain \\
\hline Mean temp. - drop & $-0.168^{* * *}$ & & \\
Mean temp. - rise & $(0.046)$ & & \\
& $0.401^{* * *}$ & & \\
Max temp. - drop & $(0.080)$ & & \\
& & $-0.086^{* * *}$ & \\
Max temp. - rise & $(0.024)$ & \\
& & $0.233^{* * *}$ & \\
Mean rain - drop & $(0.047)$ & $-0.287^{* * *}$ \\
& & & $(0.046)$ \\
Mean rain - rise & & & $0.120^{* * *}$ \\
& & & $(0.034)$ \\
Version - drop & & & $0.143^{* * *}$ \\
Version - rise & 0.015 & 0.014 & $(0.031)$ \\
& $(0.017)$ & $(0.017)$ & $0.204^{* * *}$ \\
\hline Observations & $0.223^{* * *}$ & $0.224^{* * *}$ & $(0.023)$ \\
\hline \hline
\end{tabular}

Notes. Multinomial logit. Marginal effects are reported for the probability of drop and rise outcomes at means; ${ }^{* *},{ }^{* *},{ }^{*}$ indicate two-sided significance levels at 1, 5, and $10 \%$, respectively; standard errors (in parentheses) clustered the sub-county level.

data is only 0.238 for the temperature changes and 0.247 for the rainfall. Given this weak predictive power, it is difficult to say which version of the questionnaire is 'better'. Moreover, the temperature correlation is 0.223 for the open ended version and 0.272 for the closed version, whereas the rainfall correlation is 0.313 and 0.215 respectively. These figures suggest that version 2 (the closed version) is better for temperature, while version 1 is better for rainfall, but that may well just reflect the vagaries of the location and recent changes in its climate.

\subsection{Stated adaptation and historical evidence.}

In this section I compare the stated adaptation to historical evidence in the shape of the difference in land use measured over the course of the panel. The focus is on the difference between land management in 2018 and 2004. In Table 8 the dependent variables are the differences. The key right hand side variables are the stated answers to the questionnaire about adaptation. whether the respondent states that he or she has adopted a particular adaptation. In the case of water conservation, the variable takes values 0,1 and 2 corresponding to 'conserving less' 'no change' and 'conserving more' which we treat as a continuous variable (no change to the results is obtained if instead we use two dummy variables). Because it uses the differences between surveys, Table 8 therefore only uses data from those farmers who were interviewed in both waves. Moreover some practices are not relevant for some farmers, so the number of observations varies. The right-hand side variables do not always correspond exactly to the dependent variable and some stated 
adaptations do not correspond to any data in the RePeat survey so we ignore them. ${ }^{10}$ Alongside, the stated change, I also include change in mean precipitation variable from the satellite data, and the subject's perception of temperature and precipitation change. ${ }^{11}$ Standard errors are clustered at the sub-county level.

Table 8: Stated adaptation and measured change: crops.

\begin{tabular}{|c|c|c|c|c|c|}
\hline & $\begin{array}{c}(1) \\
\mathrm{N} \text { seeds }\end{array}$ & $\begin{array}{c}(2) \\
\text { New crops }\end{array}$ & $\begin{array}{c}(3) \\
\mathrm{N} \text { crops }\end{array}$ & $\begin{array}{c}(4) \\
\text { Cropped Area }\end{array}$ & $\begin{array}{c}(5) \\
\text { Intercrop area }\end{array}$ \\
\hline Change, mean precip. & $\begin{array}{l}-0.164 \\
(0.116)\end{array}$ & $\begin{array}{c}0.021 \\
(0.139)\end{array}$ & $\begin{array}{c}0.228 \\
(0.351)\end{array}$ & $\begin{array}{c}-0.126 \\
(0.733)\end{array}$ & $\begin{array}{c}0.023 \\
(0.077)\end{array}$ \\
\hline Version & $\begin{array}{l}-0.038 \\
(0.049)\end{array}$ & $\begin{array}{c}0.093 \\
(0.061)\end{array}$ & $\begin{array}{l}-0.064 \\
(0.211)\end{array}$ & $\begin{array}{l}-0.461 \\
(0.323)\end{array}$ & $\begin{array}{l}-0.015 \\
(0.037)\end{array}$ \\
\hline Temperature Change & $\begin{array}{l}-0.001 \\
(0.003)\end{array}$ & $\begin{array}{l}0.006^{* *} \\
(0.002)\end{array}$ & $\begin{array}{l}-0.009 \\
(0.011)\end{array}$ & $\begin{array}{l}0.026^{* *} \\
(0.011)\end{array}$ & $\begin{array}{l}0.002^{*} \\
(0.001)\end{array}$ \\
\hline Rain change & $\begin{array}{l}-0.001 \\
(0.003)\end{array}$ & $\begin{array}{l}-0.002 \\
(0.004)\end{array}$ & $\begin{array}{l}0.020^{* *} \\
(0.008)\end{array}$ & $\begin{array}{l}-0.005 \\
(0.011)\end{array}$ & $\begin{array}{l}-0.000 \\
(0.003)\end{array}$ \\
\hline Planted different varieties & $\begin{array}{c}0.260^{* * *} \\
(0.088)\end{array}$ & & & & \\
\hline Planted different crops & & $\begin{array}{l}0.185^{* *} \\
(0.083)\end{array}$ & & & \\
\hline Crop diversification & & & $\begin{array}{c}-0.422 \\
(0.279)\end{array}$ & & \\
\hline Changed land quantity & & & & $\begin{array}{c}1.055 \\
(0.660)\end{array}$ & \\
\hline Introduced intercropping & & & & & $\begin{array}{l}0.136^{* *} \\
(0.053)\end{array}$ \\
\hline Constant & $\begin{array}{c}-0.744^{* * *} \\
(0.154) \\
\end{array}$ & $\begin{array}{l}0.417^{* *} \\
(0.168) \\
\end{array}$ & $\begin{array}{c}-4.418^{* * *} \\
(0.535) \\
\end{array}$ & $\begin{array}{r}0.363 \\
(0.765) \\
\end{array}$ & $\begin{array}{c}-0.440^{* * *} \\
(0.104) \\
\end{array}$ \\
\hline Observations & 655 & 1105 & 655 & 675 & 655 \\
\hline
\end{tabular}

As can be seen, in Table 8 for three cases out of five there is a statistically significant

\footnotetext{
${ }^{10}$ These adaptations are: Different planting dates/Earlier planting/Later planting, Shading and sheltering / tree planting, Used insurance or weather derivatives, Prayer or ritual offering. Possibly the first of these is the most important, but the dates of planting were not recorded in the RePEAT panel and it is not possible to reliably infer them from the database.

${ }^{11}$ I do not use any personal characteristics of the farms or farmers in these Tables, mainly because actual surveys of farmer perceptions will vary in the degree to which such information is available. Perhaps not surprisingly, it turns out that including some personal information can, for at least some equations, be predictive for changes in land management, though it seems to vary by question. However, the important point is that including other farm and farmer information does not alter the basic conclusion that stated adaptation is typically not predictive for historical change.
} 
relationship between actual change and stated change. Table 9 shows a different and less reassuring story. Stated adaptation is not predictive for actual adaptation in four out of five cases. However, the changes in livestock practice variable is predictive for an increased fraction of open grazed cows.

Table 9: Stated adaptation and measured change: livestock, land, livelihoods.

\begin{tabular}{|c|c|c|c|c|c|}
\hline & $\begin{array}{c}(1) \\
\text { Inorganic }\end{array}$ & $\begin{array}{c}(2) \\
\text { Fodder }\end{array}$ & $\begin{array}{c}(3) \\
\text { Businesses }\end{array}$ & $\begin{array}{c}(4) \\
\text { Non-rain }\end{array}$ & $\begin{array}{c}(5) \\
\text { Open grazed }\end{array}$ \\
\hline Change, mean precip. & $\begin{array}{l}0.122^{* *} \\
(0.053)\end{array}$ & $\begin{array}{l}-0.008 \\
(0.023)\end{array}$ & $\begin{array}{c}-0.162^{* *} \\
(0.072)\end{array}$ & $\begin{array}{l}-0.017 \\
(0.050)\end{array}$ & $\begin{array}{l}-0.096 \\
(0.072)\end{array}$ \\
\hline Version & $\begin{array}{l}-0.066 \\
(0.040)\end{array}$ & $\begin{array}{c}0.003 \\
(0.012)\end{array}$ & $\begin{array}{c}0.076 \\
(0.047)\end{array}$ & $\begin{array}{c}0.037 \\
(0.025)\end{array}$ & $\begin{array}{l}-0.015 \\
(0.061)\end{array}$ \\
\hline Temperature Change & $\begin{array}{c}0.001 \\
(0.001)\end{array}$ & $\begin{array}{c}-0.001^{* * *} \\
(0.000)\end{array}$ & $\begin{array}{c}0.000 \\
(0.002)\end{array}$ & $\begin{array}{c}0.000 \\
(0.001)\end{array}$ & $\begin{array}{l}-0.001 \\
(0.001)\end{array}$ \\
\hline Rain change & $\begin{array}{l}-0.000 \\
(0.003)\end{array}$ & $\begin{array}{c}0.000 \\
(0.000)\end{array}$ & $\begin{array}{l}-0.001 \\
(0.003)\end{array}$ & $\begin{array}{l}-0.000 \\
(0.002)\end{array}$ & $\begin{array}{c}0.000 \\
(0.001)\end{array}$ \\
\hline Changed use of chemical/fertilizer & $\begin{array}{c}0.017 \\
(0.054)\end{array}$ & & & & \\
\hline Switched towards crops & & $\begin{array}{c}0.003 \\
(0.013)\end{array}$ & & & \\
\hline Increased non-farm activities & & & $\begin{array}{l}-0.067 \\
(0.052)\end{array}$ & & \\
\hline Increased non-rainfed & & & & $\begin{array}{l}-0.082 \\
(0.058)\end{array}$ & \\
\hline Livestock changes & & & & & $\begin{array}{l}0.170^{* *} \\
(0.078)\end{array}$ \\
\hline Constant & $\begin{array}{c}0.309^{* * *} \\
(0.117)\end{array}$ & $\begin{array}{c}-0.054^{* *} \\
(0.024)\end{array}$ & $\begin{array}{l}0.198^{* *} \\
(0.091)\end{array}$ & $\begin{array}{c}0.127^{*} \\
(0.074)\end{array}$ & $\begin{array}{c}-0.341^{* *} \\
(0.154)\end{array}$ \\
\hline Observations & 643 & 680 & 677 & 694 & 313 \\
\hline
\end{tabular}

In Table 10, I present the relationship between stated conservation practice changes and historical measurement. The stated adaptation 'increased tree planting' is predictive for the measure of trees planted for conservation and fraction of plots with trees planted for conservation. For the other two variables there are no statistically robust links between stated adaptations and historical changes in land management.

Overall, therefore, out of the 14 items in the three tables, six are predictive in a way that is compatible with the definition of the variable, while eight are not. ${ }^{12}$ Several of these

\footnotetext{
${ }^{12}$ Some care has to be taken over the meaning of the word 'predictive' here. For example, reported intercropping is predictive of the historical record of change. However, according to the panel, intercropping has diminished over the sample period, whereas according to the climate change model, farmers
} 
insignificant variables actually have a sign at variance with expectations. While I have considered other possible measures of adaptation (e.g. unweighted by are of plots), the pattern that emerges is similar to what is presented here: on the whole stated adaptations are not predictive for adaptations as measured by the historical record.

Table 10: Stated adaptation and measured change: conservation.

\begin{tabular}{|c|c|c|c|c|}
\hline & $\begin{array}{c}(1) \\
\text { Organic }\end{array}$ & $\begin{array}{c}(2) \\
\text { Water }\end{array}$ & $\begin{array}{c}\text { (3) } \\
\text { Trees }\end{array}$ & $\begin{array}{c}(4) \\
\text { Trees II }\end{array}$ \\
\hline Change, mean precip. & $\begin{array}{c}-0.212^{* * *} \\
(0.062)\end{array}$ & $\begin{array}{c}0.083 \\
(0.068)\end{array}$ & $\begin{array}{c}-3.978 \\
(39.897)\end{array}$ & $\begin{array}{c}0.308^{* * *} \\
(0.081)\end{array}$ \\
\hline Version & $\begin{array}{c}0.006 \\
(0.033)\end{array}$ & $\begin{array}{l}-0.052 \\
(0.044)\end{array}$ & $\begin{array}{l}76.410^{* *} \\
(35.963)\end{array}$ & $\begin{array}{l}-0.020 \\
(0.045)\end{array}$ \\
\hline Temperature Change & $\begin{array}{l}-0.001 \\
(0.002)\end{array}$ & $\begin{array}{c}-0.001 \\
(0.003)\end{array}$ & $\begin{array}{c}0.310 \\
(0.697)\end{array}$ & $\begin{array}{c}0.001 \\
(0.002)\end{array}$ \\
\hline Rain change & $\begin{array}{c}0.001 \\
(0.001)\end{array}$ & $\begin{array}{l}-0.000 \\
(0.002)\end{array}$ & $\begin{array}{l}-0.195 \\
(0.396)\end{array}$ & $\begin{array}{l}-0.000 \\
(0.002)\end{array}$ \\
\hline Used soil conservation & $\begin{array}{l}-0.053 \\
(0.056)\end{array}$ & & & \\
\hline Increased water conservation & & $\begin{array}{c}-0.004 \\
(0.047)\end{array}$ & & \\
\hline Trees and conservation & & & $\begin{array}{l}74.851^{* *} \\
(37.592)\end{array}$ & $\begin{array}{l}0.169^{* *} \\
(0.072)\end{array}$ \\
\hline Constant & $\begin{array}{c}0.167 \\
(0.111)\end{array}$ & $\begin{array}{c}-0.549^{* * *} \\
(0.096)\end{array}$ & $\begin{array}{c}-280.941^{* * *} \\
(84.870)\end{array}$ & $\begin{array}{l}-0.222^{*} \\
(0.117)\end{array}$ \\
\hline Observations & 657 & 649 & 633 & 633 \\
\hline
\end{tabular}

\subsection{Robustness}

One possibility is that farmers who report no climate change are simply providing noise values for adaptations and this masks the relationships between historical and stated adaptations. As a robustness check, I examine the relationships for only the subsample of farmers who reported at least one climatic change. Appendix II contains an illustrative table of results that corresponds to Table 8 in the main text. The results are not substantively different: the key variables that are statistically significant in the main text are also significant with the same signs in the Appendix II. Table A2.2 in Appendix II includes 'no change noticed' as a dummy explanatory variable: in only one case is it

report actually higher use of intercropping. The positive correlation occurs because farmers who have reduced intercropping more are less likely to report that they have increased intercropping. 
significant, suggesting that the historical pattern of adaptation is largely independent of whether the farmer has noted a change in climate, once other variables are controlled for.

Another possibility is that the period of the panel from 2004 to 2018 is just too long for farmers to remember exactly and so they are reporting change from a more recent date. Appendix II also includes Table A2.3 which uses the differences between 2012 and 2018 as the dependent variable. This also makes little difference to the overall conclusion, suggesting that it is not the time period that leads to the unreliability of recall.

Table 11: Consistency of Responses.

\begin{tabular}{lcccccc}
\hline \hline & $(1)$ & $(2)$ & $(3)$ & $(4)$ & $(5)$ & $(6)$ \\
& Accuracy & New crops & Water & Crop to Cow & Temp. & Rain \\
\hline Version & 0.006 & 0.012 & 0.042 & -0.030 & $0.196^{* * *}$ & 0.048 \\
& $(0.016)$ & $(0.036)$ & $(0.034)$ & $(0.034)$ & $(0.028)$ & $(0.035)$ \\
Change, mean precip. & -0.040 & -0.006 & 0.022 & $-0.171^{* * *}$ & $-0.527^{* * *}$ & -0.072 \\
& $(0.031)$ & $(0.038)$ & $(0.048)$ & $(0.054)$ & $(0.034)$ & $(0.059)$ \\
Sex & -0.004 & -0.025 & 0.005 & 0.048 & -0.010 & 0.018 \\
& $(0.016)$ & $(0.030)$ & $(0.031)$ & $(0.037)$ & $(0.026)$ & $(0.041)$ \\
Age & 0.000 & 0.000 & 0.001 & 0.000 & 0.001 & 0.001 \\
& $(0.001)$ & $(0.001)$ & $(0.001)$ & $(0.001)$ & $(0.001)$ & $(0.001)$ \\
Highest Education & -0.001 & 0.003 & -0.000 & -0.000 & 0.003 & -0.003 \\
& $(0.002)$ & $(0.002)$ & $(0.002)$ & $(0.003)$ & $(0.002)$ & $(0.002)$ \\
Household size & -0.003 & $-0.009^{*}$ & -0.002 & 0.001 & $-0.006^{*}$ & $-0.009^{*}$ \\
Maths & $(0.002)$ & $(0.005)$ & $(0.006)$ & $(0.005)$ & $(0.003)$ & $(0.005)$ \\
Farm area 2018 & 0.002 & $0.024^{* *}$ & 0.003 & $-0.029^{*}$ & 0.014 & 0.018 \\
& $(0.007)$ & $(0.010)$ & $(0.013)$ & $(0.016)$ & $(0.012)$ & $(0.016)$ \\
\hline Observations & $0.002^{* * *}$ & 0.000 & 0.003 & -0.004 & 0.002 & $0.004^{*}$ \\
& $(0.001)$ & $(0.003)$ & $(0.003)$ & $(0.003)$ & $(0.003)$ & $(0.002)$ \\
\hline
\end{tabular}

Notes. $^{* * *},{ }^{* *},{ }^{*}$ indicate two-sided significance levels at 1,5 , and $10 \%$, respectively; standard errors (in parentheses) clustered at the sub-county level. The first equation is OLS; all others estimated by logit. Accuracy = index of congruence between stated change (up, down, no change) and historical change for six items; "New crops", "Water",

"Crop to cow" are three specific instances for introduction of new crops, switching towards water conservation and moving from land for crops to livestock. Temp. and "Rain" are binary variables measuring congruence between stated changes in temperature and rain and the historical record. The individual variables are for the person who answered the main land use questions.

Table 11 examines whether there are clear factors that predict the congruence between the individual responses and the historical records. The first equation is an OLS regression of an index of accuracy on various factors. The index is the mean score for six items: introduction of new crops, changes in water conservation, moving from crops to livestock, changing the farmed area, change in use of rain-fed agriculture, change in non-farm business. ${ }^{13}$ The mean of this accuracy variable is 0.53 which is statistically

\footnotetext{
${ }^{13}$ All the variables take on either two levels (positive, negative or no change and increase) or three (up, no change, down).
} 
significantly different $(p<0.01$, t-test) from 0.5 . For the right hand side variables I use the version as well as the satellite based estimates of change in mean precipitation. Mean changes in temperature are omitted since these are so heavily (negatively) correlated with the precipitation changes. The individual variables are for the person who answers the land use questions in 2018. The "Maths" score is the number correct out of five simple arithmetic questions (e.g. what is 46-19?).

As can be seen, few of the right hand side variables show statistical significance. Maths score is positively related to getting the change in new crops correct, but negative associated with perceiving the correct direction of change of land use. No variable is frequently associated with the consistency measures. It is notable that age is not linked to accuracy, even though we might expect older people who have farmed throughout the entire period to have a better understanding of changes in practices. Similarly education or maths skill is not generally positively linked to consistency. Perhaps the strongest association is between the change in mean precipitation and the temperature variable, but this is probably just picking up the strong negative correlation between rain changes and mean temperature changes again.

\section{Discussion.}

Maddison (2007) (p21-22) identifies a number of difficulties with relying on farmer recall for the measurement of climate change adaptation. Taking my cue from this observation, I consider how questionnaire format and possible recall bias influence measures of climate change perception and adaptation for a large sample of farmers spread across rural Kenya. I find that question format has a significant and large impact on perception: perceived change is less when the questions are open ended compared to a format that is closed. In addition, some aspects of change, such as drought experience, are not picked up in open ended questions. When I compare perceived change to some actual - albeit noisy - measures of climate change from satellite data I find little correlation for either format.

In the questionnaire, subjects are asked about adaptations they have made. I find that stated adaptation to climate change is sensitive to the format for some possible adaptations. Moreover the estimated impact of the format indicator variable is often as large as the impact of perceived changes in climate.

Using questions on planting and land use from different waves of the RePEAT panel, I then use the historical data on land use to compare it to the stated adaptation for several items where we have clear data. On the whole the correlation is not large and in several cases the stated adaptation is negatively associated with the historical record, albeit not significantly so. Moreover it is not possible to identify farm or individual characteristics that are correlated with consistency between stated change and the record. This latter point suggests that focusing on particular types of informants rather than a random 
sample of farmers would not necessarily produce more reliable subjective assessments of change.

This is only one survey from one country, but nevertheless the results of this research should give pause to researchers investigating agricultural adaptation to climate change in developing countries. As to whether open or closed questions on climate change are better, it is not possible to come to a definitive view on the basis of this research. Neither method produces accurate statements about changes in land management and though the closed version provides better correlation with satellite data on climate change, the improvement compared to the open version is modest. Moreover, given the order of the questions and that the trends for temperature in most areas covered by this study are positive, it is conceivable that the higher correlation for the close-ended version may be due to yeah-saying by some respondents. While the poor correlation between perception and the satellite record may reflect the relatively small changes in climate observed so far for the study site, it also suggests that attempting to measure climate change perceptions may not have high value. It may be better to focus on data on actual land use from panels (or repeated cross-sections or ongoing satellite-based monitoring along the lines of Lobell et al. (2018) say) rather than relying on the recall of farmers. 


\section{References}

Assaad, R., Krafft, C., Yassin, S., 2018. Comparing retrospective and panel data collection methods to assess labor market dynamics. IZA Journal of Development and Migration 8, 17.

Battaglini, A., Barbeau, G., Bindi, M., Badeck, F.W., 2009. European winegrowers' perceptions of climate change impact and options for adaptation. Regional Environmental Change 9, 61-73. URL: https://doi.org/10.1007/s10113-008-0053-9, doi:10.1007/s10113-008-0053-9.

Beegle, K., Carletto, C., Himelein, K., 2012. Reliability of recall in agricultural data. Journal of Development Economics 1, 34-41.

Bryan, E., Ringler, C., Okoba, B., Roncoli, C., Silvestri, S., Herrero, M., 2013. Adapting agriculture to climate change in Kenya: Household strategies and determinants. Journal of environmental management 114, 26-35.

Budhathoki, N.K., Zander, K.K., 2019. Nepalese farmers' climate change perceptions, reality and farming strategies. Climate and Development , 1-12.

Choi, B.C., Pak, A.W., 2005. Peer reviewed: a catalog of biases in questionnaires. Preventing chronic disease 2.

De Jalón, S.G., Silvestri, S., Granados, A., Iglesias, A., 2015. Behavioural barriers in response to climate change in agricultural communities: an example from Kenya. Regional Environmental Change 15, 851-865.

Deressa, T.T., Hassan, R.M., Ringler, C., Alemu, T., Yesuf, M., 2009. Determinants of farmers' choice of adaptation methods to climate change in the Nile Basin of Ethiopia. Global environmental change 19, 248-255.

Desiere, S., Jolliffe, D., 2018. Land productivity and plot size: Is measurement error driving the inverse relationship? Journal of Development Economics 130, 84 - 98. URL: http://www.sciencedirect.com/science/article/pii/S0304387817300810, doi:https://doi.org/10.1016/j.jdeveco.2017.10.002.

Fosu-Mensah, B.Y., Vlek, P.L., MacCarthy, D.S., 2012. Farmers' perception and adaptation to climate change: a case study of Sekyedumase district in Ghana. Environment, Development and Sustainability 14, 495-505.

Gbetibouo, G.A., 2009. Understanding farmers' perceptions and adaptations to climate change and variability: The case of the Limpopo Basin, South Africa. volume 849. Intl Food Policy Res Inst. 
Geer, J.G., 1991. Do open-ended questions measure "salient" issues? Public Opinion Quarterly 55, 360-370.

Gray, C.L., 2011. Soil quality and human migration in kenya and uganda. Global Environmental Change 21, 421-430.

Habiba, U., Shaw, R., Takeuchi, Y., 2012. Farmer's perception and adaptation practices to cope with drought: Perspectives from Northwestern Bangladesh. International Journal of Disaster Risk Reduction 1, 72-84.

Habtemariam, L.T., Gandorfer, M., Kassa, G.A., Heissenhuber, A., 2016. Factors influencing smallholder farmers' climate change perceptions: A study from farmers in Ethiopia. Environmental Management 58, 343-358. URL: https://doi.org/10.1007/s00267-016-0708-0, doi:10.1007/s00267-016-0708-0.

Hansen, J., Sato, M., Ruedy, R., 2012. Perception of climate change. Proceedings of the National Academy of Sciences 109, E2415-E2423.

IPCC, 2014. Climate Change 2014-Impacts, Adaptation and Vulnerability: Regional Aspects. Intergovernmental Panel on Climate Change,Cambridge University Press.

Kahneman, D., 2003. A perspective on judgment and choice: mapping bounded rationality. American psychologist 58, 697.

Krosnick, J.A., 1999. Survey research. Annual review of psychology 50, 537-567.

Kurukulasuriya, P., Mendelsohn, R., Hassan, R., Benhin, J., Deressa, T., Diop, M., Eid, H.M., Fosu, K.Y., Gbetibouo, G., Jain, S., et al., 2006. Will african agriculture survive climate change? The World Bank Economic Review 20, 367-388.

Le Dang, H., Li, E., Nuberg, I., Bruwer, J., 2014. Understanding farmers' adaptation intention to climate change: A structural equation modelling study in the Mekong Delta, Vietnam. Environmental Science \& Policy 41, 11-22.

Li, X., Wang, Z., Hou, X., Liu, Z., Yin, Y., Ding, Y., Hu, J., et al., 2014. Herders' perception of climate change does not always fit with actual climate change. The Rangeland Journal 36, 557-564.

Lobell, D.B., Azzari, G., Burke, M., Gourlay, S., Jin, Z., Kilic, T., Murray, S., 2018. Eyes in the sky, boots on the ground: assessing satellite-and ground-based approaches to crop yield measurement and analysis in Uganda. The World Bank.

Maddison, D., 2007. The perception of and adaptation to climate change in Africa. volume 4308. World Bank Publications. 
Marlon, J.R., van der Linden, S., Howe, P.D., Leiserowitz, A., Woo, S.H.L., Broad, K., 2018. Detecting local environmental change: the role of experience in shaping risk judgments about global warming. Journal of Risk Research 0, 1-15. doi:10.1080/13669877.2018.1430051, arXiv:https://doi.org/10.1080/13669877.2018.1430051.

Muto, M., Yamano, T., 2009. The impact of mobile phone coverage expansion on market participation: Panel data evidence from uganda. World development 37, 1887-1896.

Mwesigye, F., Matsumoto, T., 2016. The effect of population pressure and internal migration on land conflicts: implications for agricultural productivity in Uganda. World Development 79, 25-39.

Roco, L., Engler, A., Bravo-Ureta, B.E., Jara-Rojas, R., 2015. Farmers' perception of climate change in Mediterranean Chile. Regional Environmental Change 15, 867-879. URL: https : //doi .org/10.1007/s10113-014-0669-x, doi:10.1007/s10113-014-0669$\mathrm{x}$.

Schuman, H., Presser, S., 1996. Questions and answers in attitude surveys: Experiments on question form, wording, and context. Sage.

Schwarz, N., 1999. Self-reports: how the questions shape the answers. American psychologist 54, 93.

Silvestri, S., Bryan, E., Ringler, C., Herrero, M., Okoba, B., 2012. Climate change perception and adaptation of agro-pastoral communities in Kenya. Regional Environmental Change 12, 791-802.

Simelton, E., Quinn, C.H., Batisani, N., Dougill, A.J., Dyer, J.C., Fraser, E.D., Mkwambisi, D., Sallu, S., Stringer, L.C., 2013. Is rainfall really changing? farmers' perceptions, meteorological data, and policy implications. Climate and development 5, $123-138$.

Singh, N.P., Anand, B., Khan, M.A., 2018. Micro-level perception to climate change and adaptation issues: A prelude to mainstreaming climate adaptation into developmental landscape in India. Natural Hazards 92, 1287-1304. URL: https://doi.org/10.1007/s11069-018-3250-y, doi:10.1007/s11069-018-3250-y.

Tanaka, Y., Munro, A., 2014. Regional variation in risk and time preferences: Evidence from a large-scale field experiment in rural Uganda. Journal of African Economies 23, $151-187$.

Waha, K., Zipf, B., Kurukulasuriya, P., Hassan, R.M., 2016. An agricultural survey for more than 9,500 African households. Scientific Data 3. Http://dx.doi.org/10.1038/sdata.2016.20. 
Weber, E.U., 2010. What shapes perceptions of climate change? Wiley Interdisciplinary Reviews: Climate Change 1, 332-342.

Yamano, T., Sserunkuuma, D., Otsuka, K., Omiat, G., Ainembabazi, J.H., Shimamura, Y., 2004. The 2003 REPEAT survey in Uganda: results. FASID Development Database , 09-01.

Yamauchi, C., Manang, F.E., 2019. The impact of access to health facilities on maternal care use, travel patterns and health status: Evidence from longitudinal data from Uganda. Economic Development and Cultural Change URL: https://doi.org/10.1086/702794, doi:10.1086/702794, arXiv:https://doi.org/10.1086/702794. 


\section{Appendix. I}

\section{Version 1.}

1. Thinking back to 2003 (when the first Repeat survey was done) have you noticed any long term changes in the average temperature on your farm? (please explain). (record key phrases. Do not prompt subject)

2. Thinking back to 2003 (when the first Repeat survey was done) have you noticed any long term changes in the average rainfall on your farm? (please explain) (record key phrases. Do not prompt subject)

\section{Version 2.}

1. Thinking back to 2003 (when the first Repeat survey was done), have you noticed any of the following long term changes in the average temperature on your farm?

(a) Increased average temperatures $1=$ Yes, $2=$ No, $99=$ Don't know

(b) Decreased average temperatures $1=$ Yes, $2=$ No, $99=$ Don't know

(c) Altered Temperature range (the gap between lowest and highest temperatures has got bigger/small) $1=$ bigger, $2=$ smaller, $3=$ No change, $99=$ Don't know

2. Thinking back to 2003 (when the first Repeat survey was done), have you noticed any of the following long term changes in the average rainfall on your farm? ( $1=$ Yes, $2=$ No, $99=$ Don't know)
(a) Increased rainfall /an extended rainy season
(b) Decreased rainfall / a shortened rainy season
(c) The rains come earlier
(d) The rains come later
(e) There are more periods of drought
(f) There are fewer periods of drought

Both versions.

1. What adjustments in your farming have you made to these long term shifts
(a) Planted different varieties
(b) Planted different crops
(c) Crop diversification
(d) Introduced inter-cropping
(e) Different planting dates
(f) Earlier planting
(g) Later planting
(h) Changing quantity of land under cultivation
(i) Change from crops to livestock
(j) Change from livestock to crops
(k) Made adjustments to livestock management
(l) Change from farming to non-farming activity 
(m) Change from non-farming to farming activity

(n) Increased use of irrigation / groundwater / watering

(o) Decreased use of irrigation / groundwater / watering

(p) Changed use of chemicals and fertilisers

(q) Increased use of water conservation techniques

(r) Decreased use of water conservation techniques

(s) Used soil conservation techniques

(t) Shading and sheltering / tree planting

(u) Used insurance or weather derivatives

(v) Prayer or ritual offering

(w) Other [specify]

(x) Made no adaptation 


\section{Appendix II.}

Table A2.1: Stated adaptation and measured change with only change noticers: crops.

\begin{tabular}{|c|c|c|c|c|c|}
\hline & $\begin{array}{c}(1) \\
\mathrm{N} \text { seeds }\end{array}$ & $\begin{array}{c}(2) \\
\text { New crops }\end{array}$ & $\begin{array}{l}(3) \\
\mathrm{N} \text { crops }\end{array}$ & $\begin{array}{c}(4) \\
\text { Cropped Area }\end{array}$ & $\begin{array}{c}(5) \\
\text { Intercrop area }\end{array}$ \\
\hline Change, mean precip. & $\begin{array}{l}-0.220^{*} \\
(0.127)\end{array}$ & $\begin{array}{c}0.018 \\
(0.144)\end{array}$ & $\begin{array}{c}0.217 \\
(0.368)\end{array}$ & $\begin{array}{l}-0.017 \\
(0.704)\end{array}$ & $\begin{array}{c}0.055 \\
(0.081)\end{array}$ \\
\hline Version & $\begin{array}{l}-0.012 \\
(0.053)\end{array}$ & $\begin{array}{c}0.056 \\
(0.065)\end{array}$ & $\begin{array}{c}-0.034 \\
(0.227)\end{array}$ & $\begin{array}{l}-0.367 \\
(0.382)\end{array}$ & $\begin{array}{c}-0.036 \\
(0.039)\end{array}$ \\
\hline Temperature Change & $\begin{array}{l}-0.002 \\
(0.003)\end{array}$ & $\begin{array}{l}0.005^{* *} \\
(0.002)\end{array}$ & $\begin{array}{l}-0.008 \\
(0.012)\end{array}$ & $\begin{array}{l}0.027^{* *} \\
(0.011)\end{array}$ & $\begin{array}{l}0.002^{*} \\
(0.001)\end{array}$ \\
\hline Rain change & $\begin{array}{l}-0.001 \\
(0.003)\end{array}$ & $\begin{array}{l}-0.002 \\
(0.004)\end{array}$ & $\begin{array}{l}0.019^{* *} \\
(0.008)\end{array}$ & $\begin{array}{c}-0.004 \\
(0.011)\end{array}$ & $\begin{array}{l}-0.000 \\
(0.003)\end{array}$ \\
\hline Planted different varieties & $\begin{array}{l}0.245^{* *} \\
(0.093)\end{array}$ & & & & \\
\hline Planted different crops & & $\begin{array}{l}0.212^{* *} \\
(0.086)\end{array}$ & & & \\
\hline Crop diversification & & & $\begin{array}{l}-0.369 \\
(0.300)\end{array}$ & & \\
\hline Changed land quantity & & & & $\begin{array}{c}1.055 \\
(0.755)\end{array}$ & \\
\hline Introduced intercropping & & & & & $\begin{array}{l}0.116^{* *} \\
(0.057)\end{array}$ \\
\hline Constant & $\begin{array}{c}-0.761^{* * *} \\
(0.171)\end{array}$ & $\begin{array}{c}0.454^{* * *} \\
(0.172)\end{array}$ & $\begin{array}{c}-4.555^{* * *} \\
(0.597)\end{array}$ & $\begin{array}{c}0.252 \\
(0.827) \\
\end{array}$ & $\begin{array}{c}-0.380^{* * *} \\
(0.117)\end{array}$ \\
\hline Observations & 578 & 999 & 578 & 598 & 579 \\
\hline
\end{tabular}

Notes. This table uses a sub-sample of participants: those who report at least one climate change. ${ }^{* * *}$, ${ }^{* *}{ }^{*}$ indicate two-sided significance levels at 1, 5, and $10 \%$, respectively; standard errors (in parentheses) clustered the sub-county level. $\mathrm{N}$ seeds $=\Delta$ number of seed types; New crops $=$ crops in 2018 , but not in $2004 ; \mathrm{N}$ crops $=\Delta$ number of crop types; Inter-crop $=\Delta$ fraction of inter-cropped plots; Inter-crop area $=\Delta$ fraction of cropped area that is inter-cropped 
Table A2.2: Stated adaptation and measured change and change noticers.

\begin{tabular}{|c|c|c|c|c|c|}
\hline & $\begin{array}{c}(1) \\
\mathrm{N} \text { seeds }\end{array}$ & $\begin{array}{c}(2) \\
\text { New crops }\end{array}$ & $\begin{array}{c}(3) \\
\mathrm{N} \text { crops }\end{array}$ & $\begin{array}{c}(4) \\
\text { Cropped Area }\end{array}$ & $\begin{array}{c}(5) \\
\text { Intercrop area }\end{array}$ \\
\hline Change, mean precip. & $\begin{array}{l}-0.167 \\
(0.117)\end{array}$ & $\begin{array}{c}0.031 \\
(0.138)\end{array}$ & $\begin{array}{c}0.222 \\
(0.350)\end{array}$ & $\begin{array}{l}-0.106 \\
(0.729)\end{array}$ & $\begin{array}{c}0.023 \\
(0.078)\end{array}$ \\
\hline Version & $\begin{array}{l}-0.025 \\
(0.051)\end{array}$ & $\begin{array}{c}0.050 \\
(0.061)\end{array}$ & $\begin{array}{l}-0.039 \\
(0.222)\end{array}$ & $\begin{array}{l}-0.548 \\
(0.369)\end{array}$ & $\begin{array}{l}-0.015 \\
(0.038)\end{array}$ \\
\hline Temperature Change & $\begin{array}{l}-0.001 \\
(0.003)\end{array}$ & $\begin{array}{l}0.005^{* *} \\
(0.002)\end{array}$ & $\begin{array}{l}-0.008 \\
(0.011)\end{array}$ & $\begin{array}{l}0.026^{* *} \\
(0.011)\end{array}$ & $\begin{array}{l}0.002^{*} \\
(0.001)\end{array}$ \\
\hline Rain change & $\begin{array}{l}-0.001 \\
(0.003)\end{array}$ & $\begin{array}{l}-0.001 \\
(0.004)\end{array}$ & $\begin{array}{l}0.020^{* *} \\
(0.008)\end{array}$ & $\begin{array}{l}-0.004 \\
(0.011)\end{array}$ & $\begin{array}{l}-0.000 \\
(0.003)\end{array}$ \\
\hline Planted different varieties & $\begin{array}{l}0.258^{* * *} \\
(0.088)\end{array}$ & & & & \\
\hline No change noticed & $\begin{array}{c}0.064 \\
(0.113)\end{array}$ & $\begin{array}{c}-0.252^{* *} \\
(0.111)\end{array}$ & $\begin{array}{c}0.130 \\
(0.384)\end{array}$ & $\begin{array}{l}-0.466 \\
(0.650)\end{array}$ & $\begin{array}{c}0.002 \\
(0.079)\end{array}$ \\
\hline Planted different crops & & $\begin{array}{l}0.185^{* *} \\
(0.084)\end{array}$ & & & \\
\hline Crop diversification & & & $\begin{array}{l}-0.422 \\
(0.280)\end{array}$ & & \\
\hline Changed land quantity & & & & $\begin{array}{c}1.073 \\
(0.666)\end{array}$ & \\
\hline Introduced intercropping & & & & & $\begin{array}{l}0.136^{* *} \\
(0.053)\end{array}$ \\
\hline Constant & $\begin{array}{c}-0.765^{* * *} \\
(0.163)\end{array}$ & $\begin{array}{l}0.505^{* * *} \\
(0.167)\end{array}$ & $\begin{array}{c}-4.470^{* * *} \\
(0.567)\end{array}$ & $\begin{array}{c}0.523 \\
(0.807)\end{array}$ & $\begin{array}{c}-0.441^{* * *} \\
(0.109)\end{array}$ \\
\hline Observations & 655 & 1105 & 655 & 675 & 655 \\
\hline
\end{tabular}

Notes. This table uses a sub-sample of participants: those who report at least one climate change. ${ }^{* * *},{ }^{* *},{ }^{*}$ indicate two-sided significance levels at 1,5 , and $10 \%$, respectively; standard errors (in parentheses) clustered the sub-county level. N seeds $=\Delta$ number of seed types; New crops $=$ crops in 2018, but not in 2004; N crops $=\Delta$ number of crop types; Cropped Area $=\Delta$ area under crops; Inter-crop area $=\Delta$ fraction of cropped area that is inter-cropped 
Table A2.3: Stated adaptation and measured change 2012-2018

\begin{tabular}{|c|c|c|c|c|c|c|c|}
\hline & $\begin{array}{c}(1) \\
\mathrm{N} \text { seeds }\end{array}$ & $\begin{array}{c}(2) \\
\text { New crops }\end{array}$ & $\begin{array}{c}(3) \\
\mathrm{N} \text { crops }\end{array}$ & $\begin{array}{c}(4) \\
\text { Cropped A }\end{array}$ & $\begin{array}{c}(5) \\
\text { Intercrop area }\end{array}$ & $\begin{array}{c}(6) \\
\text { Fodder }\end{array}$ & $\begin{array}{c}(7) \\
\text { Businesses }\end{array}$ \\
\hline Change, mean precip. & $\begin{array}{c}0.259 \\
(0.160)\end{array}$ & $\begin{array}{c}0.018 \\
(0.139)\end{array}$ & $\begin{array}{l}0.916^{*} \\
(0.471)\end{array}$ & $\begin{array}{l}-0.262 \\
(0.271)\end{array}$ & $\begin{array}{c}0.048 \\
(0.077)\end{array}$ & $\begin{array}{c}-0.062^{* *} \\
(0.027)\end{array}$ & $\begin{array}{l}-0.045 \\
(0.073)\end{array}$ \\
\hline Version & $\begin{array}{l}-0.022 \\
(0.076)\end{array}$ & $\begin{array}{l}0.094 \\
(0.061)\end{array}$ & $\begin{array}{l}0.490^{* *} \\
(0.194)\end{array}$ & $\begin{array}{l}0.006 \\
(0.271)\end{array}$ & $\begin{array}{l}-0.037 \\
(0.034)\end{array}$ & $\begin{array}{c}0.012 \\
(0.011)\end{array}$ & $\begin{array}{l}0.006 \\
(0.051)\end{array}$ \\
\hline Temperature Change & $\begin{array}{l}-0.004 \\
(0.006)\end{array}$ & $\begin{array}{l}0.005^{* *} \\
(0.002)\end{array}$ & $\begin{array}{c}-0.021^{* *} \\
(0.009)\end{array}$ & $\begin{array}{c}0.005 \\
(0.004)\end{array}$ & $\begin{array}{c}0.002 \\
(0.002)\end{array}$ & $\begin{array}{c}0.000 \\
(0.000)\end{array}$ & $\begin{array}{c}0.001 \\
(0.002)\end{array}$ \\
\hline Rain change & $\begin{array}{c}0.005 \\
(0.006)\end{array}$ & $\begin{array}{l}-0.001 \\
(0.004)\end{array}$ & $\begin{array}{c}0.010 \\
(0.008)\end{array}$ & $\begin{array}{l}-0.001 \\
(0.004)\end{array}$ & $\begin{array}{l}-0.001 \\
(0.004)\end{array}$ & $\begin{array}{c}0.000 \\
(0.000)\end{array}$ & $\begin{array}{c}0.000 \\
(0.002)\end{array}$ \\
\hline Planted different varieties & $\begin{array}{l}0.108 \\
(0.111)\end{array}$ & & & & & & \\
\hline Planted different crops & & $\begin{array}{l}0.183^{* *} \\
(0.083)\end{array}$ & & & & & \\
\hline Crop diversification & & & $\begin{array}{l}-0.083 \\
(0.307)\end{array}$ & & & & \\
\hline Changed land quantity & & & & $\begin{array}{l}-0.430 \\
(0.348)\end{array}$ & & & \\
\hline Introduced intercropping & & & & & $\begin{array}{l}0.117^{* *} \\
(0.050)\end{array}$ & & \\
\hline Switched towards crops & & & & & & $\begin{array}{l}-0.023 \\
(0.016)\end{array}$ & \\
\hline Increased non-farm activities & & & & & & & $\begin{array}{c}-0.130^{* *} \\
(0.054)\end{array}$ \\
\hline Constant & $\begin{array}{c}-2.287^{* * *} \\
(0.211)\end{array}$ & $\begin{array}{l}0.418^{* *} \\
(0.168)\end{array}$ & $\begin{array}{c}-7.694^{* * *} \\
(0.551)\end{array}$ & $\begin{array}{c}0.066 \\
(0.439)\end{array}$ & $\begin{array}{c}-0.460^{* * *} \\
(0.100)\end{array}$ & $\begin{array}{c}0.018 \\
(0.025)\end{array}$ & $\begin{array}{c}0.328^{* * *} \\
(0.097)\end{array}$ \\
\hline Observations & 625 & 1106 & 625 & 643 & 626 & 649 & 645 \\
\hline
\end{tabular}

Notes. This table uses a sub-sample of participants: those who report at least one climate change. ${ }^{* * *},{ }^{* *},{ }^{*}$ indicate two-sided significance levels at 1,5 , and $10 \%$, respectively; standard errors (in parentheses) clustered the sub-county level. $\mathrm{N}$ seeds $=\Delta$ number of seed types; New crops $=$ crops in 2018, but not in 2004; $\mathrm{N}$ crops $=\Delta$ number of crop types; Inter-crop area $=\Delta$ fraction of cropped area that is inter-cropped 